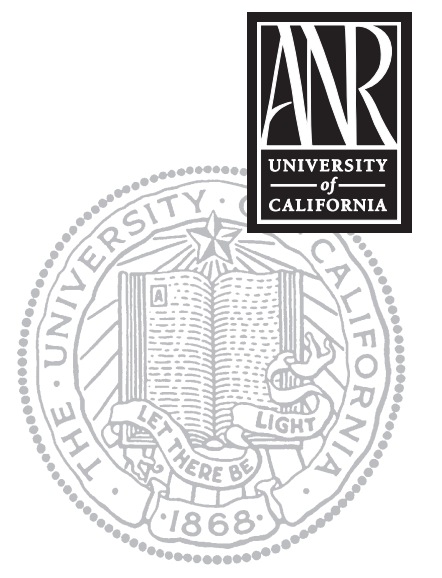

UNIVERSITY OF CALIFORNIA

Division of Agriculture and Natural Resources http://anrcatalog.ucdavis.edu

\title{
Frost Protection for Citrus and Other Subtropicals
}

PAMELA M. GEISEL, University of California Cooperative Extension Farm Advisor, Environmental Horticulture, Fresno County; CAROLYN L. UNRUH, staff writer, University of California Cooperative Extension Fresno County.

In many areas of California, winter temperatures can pose a threat to the fruit and foliage of citrus and other subtropical trees such as avocado (Persea americana), loquat (Eriobotrya japonica), guava (Psidium spp.), and macadamia (Macadamia spp.). Susceptibility to frost depends on the health and vigor of the plants, the characteristics of individual species or cultivars, the rootstock on which the individual trees are grown, and the intensity and duration of the cold.

\section{TYPES OF FROST}

Injury to plants from temperatures below freezing can be called "frost" or "freezing"; in this publication it is referred to as "frost." Plants can also be injured by cold temperatures above freezing; this is called "low-temperature injury" or "chilling injury" and is not covered in this publication (for more information on low-temperature injury, see Abiotic Disorders of Landscape Plants: A Diagnostic Guide, ANR Publication $3420,2003)$. There are two types of frost: radiation frost and advective frost.

Radiation frost occurs on cold nights when the air is clear and dry and heat is lost, or radiated, from the earth's surface into the atmosphere. Soil, buildings, plants, and other objects at the earth's surface act as a heat reservoir by absorbing heat during the day. Plants are damaged when enough heat is lost from this reservoir to lower the temperature at the surface to below critical temperatures. Radiation frost is the most common type of frost in California.

Advective frost occurs when a mass of cold air displaces a mass of warmer air at the earth's surface. This displacement can be caused by a temperature inversion, which forms when a layer of warm air creates a low ceiling that traps cold air close to the ground. Advective frost can also occur when masses of cold, polar air move into warmer areas. Advective frost is relatively uncommon in California.

\section{SYMPTOMS OF FROST INJURY}

Frost injures plants by causing ice crystals to form in plant cells, making water unavailable to plant tissues and disrupting the movement of fluids. Frost-damaged leaves or twigs appear water-soaked, wither, and turn a dark brown or black. Unprotected, sensitive young trees or regrafted trees may die, but frost seldom kills mature trees. In cold-winter areas, highly frost-sensitive trees rarely live to maturity before being killed by a frost.

Citrus fruits can be damaged by frost as well. Within a few hours after a frost, the juice vesicles inside the fruit rupture as ice crystals form inside them. This results in water loss, causing the fruit to dry out. Frost-damaged fruit can be used soon after the frost, but they break down quickly and are subject to decay by bacteria and fungi. Deterioration of frost-damaged fruit usually occurs within a few days to 2 weeks, depending on storage conditions, temperature, and other environmental factors. 


\section{SENSITIVITY TO FROST}

When gauging the temperature in your yard or garden, use a thermometer in a sheltered location. If frost is predicted and temperatures may approach the critical temperatures given below for any length of time, frost protection is warranted. Greater damage occurs with colder temperatures, a longer duration of cold, or higher relative humidity (when the air is dry, brief drops below the critical temperature may be tolerated).

\section{Trees}

Citrus varieties vary in their sensitivity to frost. Generally, when temperatures fall to $29^{\circ} \mathrm{F}\left(-1.7^{\circ} \mathrm{C}\right)$ for 30 minutes or longer, some frost damage to tender citrus plants will occur. Table 1 gives relative frost sensitivity for selected citrus trees and rootstocks.

Table 1. Relative frost sensitivity of selected citrus trees

\begin{tabular}{|c|c|c|}
\hline Common name & Scientific name & Sensitivity to frost* \\
\hline \multicolumn{3}{|c|}{ TREES } \\
\hline citron & Citrus medica & $\mathrm{H}$ \\
\hline grapefruit & Citrus $\times$ paradisi & M \\
\hline kumquat & Fortunella spp. & $\mathrm{L}$ \\
\hline lemon & Citrus limon & $\mathrm{H}$ \\
\hline lime & Citrus aurantiifolia & $\mathrm{H}$ \\
\hline mandarin orange hybrids & Citrus reticulata ssp. & M \\
\hline orange & Citrus sinensis & M \\
\hline Satsuma mandarins & Citrus reticulata ssp. & $\mathrm{L}$ \\
\hline \multicolumn{3}{|c|}{ ROOTSTOCKS } \\
\hline rough lemon or Alemow & Citrus macrophylla & $\mathrm{H}$ \\
\hline trifoliate orange & Poncirus trifoliata & M \\
\hline Troyer and Carrizo citrange & $\times$ Citronicirus Webberi & M \\
\hline
\end{tabular}

Note: * $\mathrm{H}=$ high sensitivity; $\mathrm{M}=$ moderate sensitivity; $\mathrm{L}=$ low sensitivity. Trees with a high sensitivity are more easily damaged by frost than trees with a low sensitivity. For information on frost sensitivity of particular cultivars in your area, consult reliable nursery staff or your local University of California Cooperative Extension county office.

Avocado tree varieties also vary in their tolerance of cold temperatures, although this does not appear to be affected by the rootstock. In general, the Mexican types such as Bacon, Mexicola, and Duke are the most hardy. The Guatemalan varieties, including Hass and Nabal, are quite sensitive, while Fuerte and Zutano are in the intermediate range of frost tolerance.

\section{Fruits}

The temperature at which citrus fruits are damaged depends on the species involved and the ripeness of the fruit. Critical temperatures for selected citrus fruits are given in table 2.

\section{PROTECTING TREES AND FRUIT}

\section{Planting Site}

Trees planted in open areas and trees exposed to cold prevailing winds are most likely be the first to suffer frost damage. Avoid planting frost-sensitive trees in the lowest areas of the yard or garden, as cold air tends to flow downhill and accumulate in such depressions. Trees planted near structures or walls, particularly those with a southwest exposure, absorb and retain reflected heat during the daytime and may be damaged less during periods of frost.

\section{Cultural Practices}

Proper cultural practices can play an important role in lessening the impact of frost. Healthy trees that are well supplied with water are more able to withstand frost than those that are weakened or inadequately irrigated. 
Applications of fertilizer stimulate new tender growth, as does pruning. For that reason, citrus and other subtropical trees should be fertilized and pruned during the spring and early summer so that the resulting new foliage will have enough time to mature before the onset of cold weather. Also, a full canopy helps protect the fruit more effectively during freezing conditions.

\section{Frost Protection Measures}

Protect young frost-sensitive trees by wrapping the trunks and branches with insulating material such as palm fronds, cornstalks, cardboard, or fiberglass. During wet weather, an outer covering of plastic film helps keep the insulating materials dry, but plastic alone provides very little frost protection. Cover the trunks from the ground level up to the main branches. Keep the ground around the trees as clean and as free from mulch, weeds, and ground cover as possible. Bare, moist soil radiates more heat than soil blanketed with mulch or ground cover, and this radiated heat helps protect trees from frost.

In cases where severe frosts are predicted, a 100-watt lamp (designed for outdoor use) placed in the interior of the tree will emit enough heat to reduce frost damage. Holiday lights are a festive alternative. Make sure your garden soil is moist. If the soil has good drainage, run a sprinkler system slowly or furrow-irrigate through the night. The water gives off heat, and this can help protect the trees from freezing. Also, damp soil retains heat better than dry soil, protecting roots and warming the air near the soil.

Commercial growers use large fans or wind machines to protect citrus trees from advective frosts caused by temperature inversions. The fans mix the layers of warm and cold air, raising the temperature at the surface. Wind machines, however, are seldom practical for a backyard gardener with a few trees.

\section{Pruning}

If citrus trees sustain frost damage, do not prune away dead wood or remove the trees in early spring. Wait several months in order to assess the full extent of the damage and to allow the trees to recover during warm weather. As new foliage begins to grow in the spring and early summer, frost-killed twigs and branches will become readily apparent and can be pruned out without removing viable portions of the tree. Postpone heavy pruning until the following year, so that the trees are able to regain their full canopy.

This publication has been adapted from Frost Protection of Citrus and Other Subtropicals in the Home Garden, by K. W. Opitz and R. G. Platt, University of California ANR Publication 2482, 1979. 


\section{FOR MORE INFORMATION}

You'll find more information about citrus in the following ANR sources:

Abiotic Disorders of Landscape Plants: A Diagnostic Guide, Publication 3420, 2003.

Budding and Grafting Citrus and Avocados in the Home Garden, Publication 8001, 1997. Available online at http://anrcatalog.ucdavis.edu/pdf/8001.pdf

California Master Gardener Handbook, Publication 3382, 2002.

Citrus Fruit for Home Planting, Publication 2160, 1977.

Integrated Pest Management for Citrus, Second Edition, Publication 3303, 1991.

Navel Orange Split, Publication 8038, 2001. Available online at http://anrcatalog.ucdavis.edu/pdf/8038.pdf

Protecting Citrus from Cold Losses, Publication 2372, 1979.

Pruning Citrus Trees, Publication 2449, 1976.

Funding for this publication was made possible through a grant from the Elvenia J. Slosson Fund.

Visit our online catalog at http://anrcatalog.ucdavis.edu.You can also place orders by mail, phone, or FAX, or request a printed catalog of products from

University of California

Agriculture and Natural Resources

Communication Services

6701 San Pablo Avenue, 2nd Floor

Oakland, California 94608-1239

Telephone: (800) 994-8849 or (510) 642-2431

FAX: (510) 643-5470

E-mail inquiries: danrcs@ucdavis.edu

An electronic version of this publication is available on the ANR Communication Services Web site at http://anrcatalog.ucdavis.edu.

\section{Publication 8100}

(C) 2003 by the Regents of the University of California, Division of Agriculture and Natural Resources. All rights reserved.

The University of California prohibits discrimination against or harassment of any person employed by or seeking employment with the University on the basis of race, color, national origin, religion, sex, physical or mental disability, medical condition (cancer-related or genetic characteristics), ancestry, marital status, age, sexual orientation, citizenship, or status as a covered veteran (special disabled veteran, Vietnam-era veteran or any other veteran who served on active duty during a war or in a campaign or expedition for which a campaign badge has been authorized). University Policy is intended to be consistent with the provisions of applicable State and Federal laws.

Inquiries regarding the University's nondiscrimination policies may be directed to the Affirmative Action/Staff Personnel Services Director, University of California, Agriculture and Natural Resources, 300 Lakeside Drive, 6th Floor, Oakland, CA 94612-3550 (510) 987-0096. For a free catalog of other publications, call (800) 994-8849. For help downloading this publication, call (530) 754-5112.

pr-4/03-SB/CR

ISBN 978-1-60107-274-0

This publication has been anonymously peer reviewed for technical accuracy by University of California scientists and other qualified professionals. This review process was managed by the ANR Associate Editor for Environmental Horticulture. 